\title{
Expression of the human foamy virus bel-1 transactivator in insect cells
}

\author{
Liu Hong *, Sandra Bräutigam and Axel Rethwilm \\ Institute of Virology und Immunobiology, Würzburg, Germany
}

(Received 12 March 1993; revision received and accepted 10 May 1993)

\begin{abstract}
Summary
The human foamy virus (HFV) bel-1 transactivator protein was expressed in insect cells by a recombinant baculovirus. For the generation of the recombinant baculovirus, Acbel-1, the bel-1 gene of an HFV mutant was used, that bears truncations in the bel-1 overlapping bel-2 open reading frame. Acbel-1 infected Sf 9 cells produced high amounts of recombinant protein of the same electrophoretic mobility $(36 \mathrm{kD})$ as bel-1 expressed in mammalian cells. The baculovirus expressed bel-1 protein was readily identified by a polyclonal rabbit serum directed against bel-1 in immunoblot assay. As in mammalian cells, bel-1 was predominantly localized to the nucleus of Acbel-1 infected insect cells. The baculovirus expressed bel-1 protein will be of use to determine the action of this novel viral transactivator more precisely.
\end{abstract}

Human foamy virus bel-1 transactivator; Expression in insect cells

Human foamy virus (HFV) is a member of the foamy virus subgroup of exogenous retroviruses (Teich, 1982). Foamy viruses have been isolated from Old and New World primates, felines, bovines and occasionally from man (Flügel, 1991). They replicate in a wide range of tissue culture cells giving rise to intensively vacuolated ('foamy') multinucleated syncytia (Hooks and Detrick-Hooks, 1981). In

Correspondence to: A. Rethwilm, Institut für Virologie und Immunbiologie, Versbacher Str. 7, 97078 Würzburg, Germany.

* Present address: Wuhan Institute of Virology, Wuhan 430071, P.R. China. 
their natural hosts they cause persistent infections and have been isolated from many different tissues (Hooks and Detrick-Hooks, 1981). Apart from the pathogenicity of HFV when introduced into the germ line of mice (Bothe et al., 1991), foamy viruses have never been convincingly associated with any disease (Weiss, 1988).

HFV has been molecularly cloned, sequenced, and full length infectious molecular plasmids have been constructed from subgenomic clones (Rethwilm et al., 1987, 1991; Flügel et al., 1987; Maurer et al., 1988; Löchelt et al., 1991). Nucleotide sequence analysis of HFV revealed three open reading frames (ORFs) in addition to the structural genes gag, pol, and env, which are located in the $3^{\prime}$ region of the viral genome and have been named bel (Flügel et al., 1987; Flügel, 1991). Accessory ORFs have also been discovered in the related simian foamy viruses 1 and 3 (SFV 1 and 3) (Mergia et al., 1991; Kupiec et al., 1991; Renne et al., 1992). In HFV it has been shown recently that beside the structural genes gag, pol, and env only the first of the accessory ORFs, bel-1, is required for replication in vitro (Baunach et al., 1993).

The bel-1 gene, and the respective genes of SFV-1 and 3, encode for a transactivator of viral long terminal repeat (LTR) directed transcription (Rethwilm et al., 1991; Mergia et al., 1991; Renne et al., 1993). While the dissection of bel-1 into functional domains has led to a controversial interpretation of the results (Venkatesh et al., 1993; He et al., 1993), it is principally agreed that bel-1 is an approximately $36 \mathrm{kD}$ nuclear phosphoprotein that acts on a DNA (U3) element of the LTR to augment viral transcription (Rethwilm et al., 1991; Keller et al., 1991; Venkatesh et al., 1991, 1993). The target sequence for bel-1 has been mapped to a region spanning from -471 to -93 relative to the start of transcription (Erlwein and Rethwilm, 1993). Furthermore, it has been shown that distinct fragments of this region are sufficient to respond to bel-1 (Lee et al., 1993; Erlwein and Rethwilm, 1993). However, the precise mechanism of bel-1 transactivation remains unknown. In particular, experiments to demonstrate direct binding of prokaryotically expressed bel-1 to its target sequences in the LTR have been unsuccessful (Venkatesh et al., 1993; Erlwein and Rethwilm, 1993). We therefore aimed to express bel-1 in the baculovirus system to produce a recombinant protein as a source for future studies on the action of this novel viral transactivator.

The cloning strategy for the generation of the bel-1 transfer plasmid is shown in Fig. 1. Briefly, a $1.05 \mathrm{~kb} S s p \mathrm{I}$ fragment covering the complete bel-1 coding sequence was excised from pHSRV-M6 (Baunach et al., 1993), ligated to BglII linkers and inserted into the BamHI site of the baculovirus transfer vector pAcYM1 (Matsuura et al., 1987). pHSRV-M6 is an infectious HFV plasmid with a functional bel-1 gene and two stop codons introduced into the bel-1 overlapping bel-2 ORF by in vitro mutagenesis (Baunach et al., 1993). The resulting plasmid, pAcbel-1, was used to generate recombinant bel-1 expressing baculovirus by cotransfection with AcRP23-lacZ virus DNA (Possee and Howard, 1987) into Spodoptera frugiperda (Sf9) cells. Selection of recombinants, plaque purification, and preparation of virus stocks was done according to established methods (Matsuura et al., 1987; Possee and Howard, 1987). 

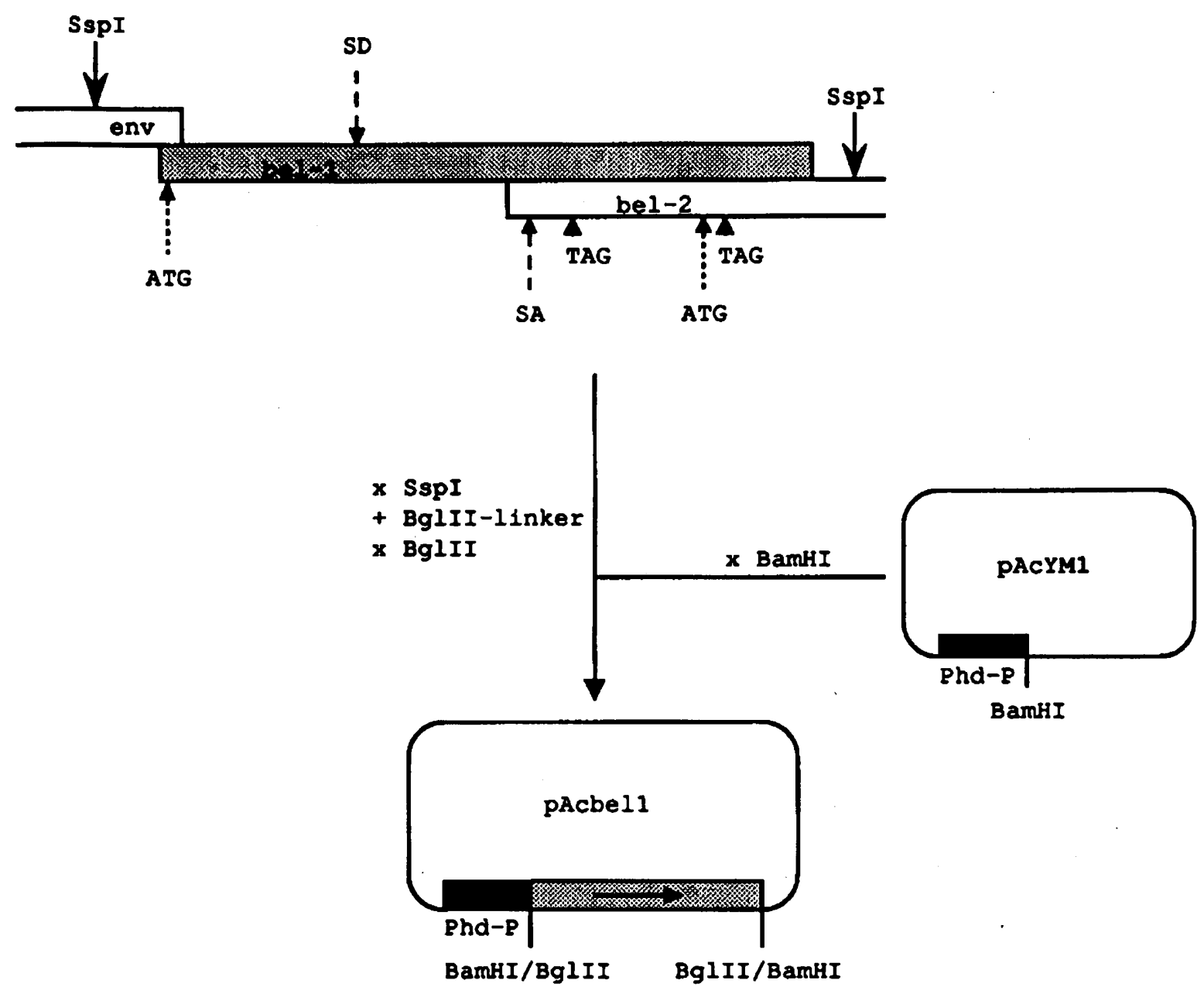

Fig. 1. Cloning strategy for the generation of pAcbel-1. BglII linkers were added to the Ssp I fragment of pHSRV mutant M6 (Baunach et al., 1993) which comprises the complete bel-1 gene of HFV. After cleavage with $B g l \mathrm{II}$ the $1.05 \mathrm{~kb}$ fragment was inserted into the Bam HI cloning site of pAcYM1 (Matsuura et al., 1987) downstream of the polyhedrin promoter (Phd-P). M6 bears two stop codons introduced into the bel-1 overlapping bel-2 ORF by in vitro mutagenesis. The mutations leave the bel-1 gene unaffected but truncate the putative bel-2 protein and a protein that is derived from an mRNA that is spliced from the bel-1 ORF (SD) into the bel-2 ORF (SA) (Baunach et al., 1993).

Insect cells infected with the recombinant baculovirus, Acbel-1, were characterized by Coomassie blue staining of proteins in infected cell extracts separated by SDS-polyacrylamide gel electrophoresis (SDS-PAGE) and by immunological methods using a polyclonal rabbit serum generated against prokaryotically expressed bel-1 (Aguzzi et al., 1993). As shown in Fig. 2A, a protein with an approximate molecular weight of $36 \mathrm{kD}$ was stained in extracts of Acbel-1 infected cells harvested $24 \mathrm{~h}$ after infection. Such a protein was not detected in lysates from uninfected or AcNPV infected Sf 9 cells. Comparison with a bovine serum albumin standard (not shown) indicated that $1 \times 10^{8} \mathrm{Sf} 9$ cells infected with Acbel-1 at an m.o.i. of 10 produce $0.1-0.2 \mathrm{mg}$ bel-1 protein after $48 \mathrm{~h}$. Western blot analysis revealed the $36 \mathrm{kD}$ protein to be specifically stained with the bel-1 antiserum (Fig. 2B). No bel-1 reactive protein was detected in the lanes containing lysates from uninfected cells or cells infected with the control virus. The novel Acbel-1 encoded 


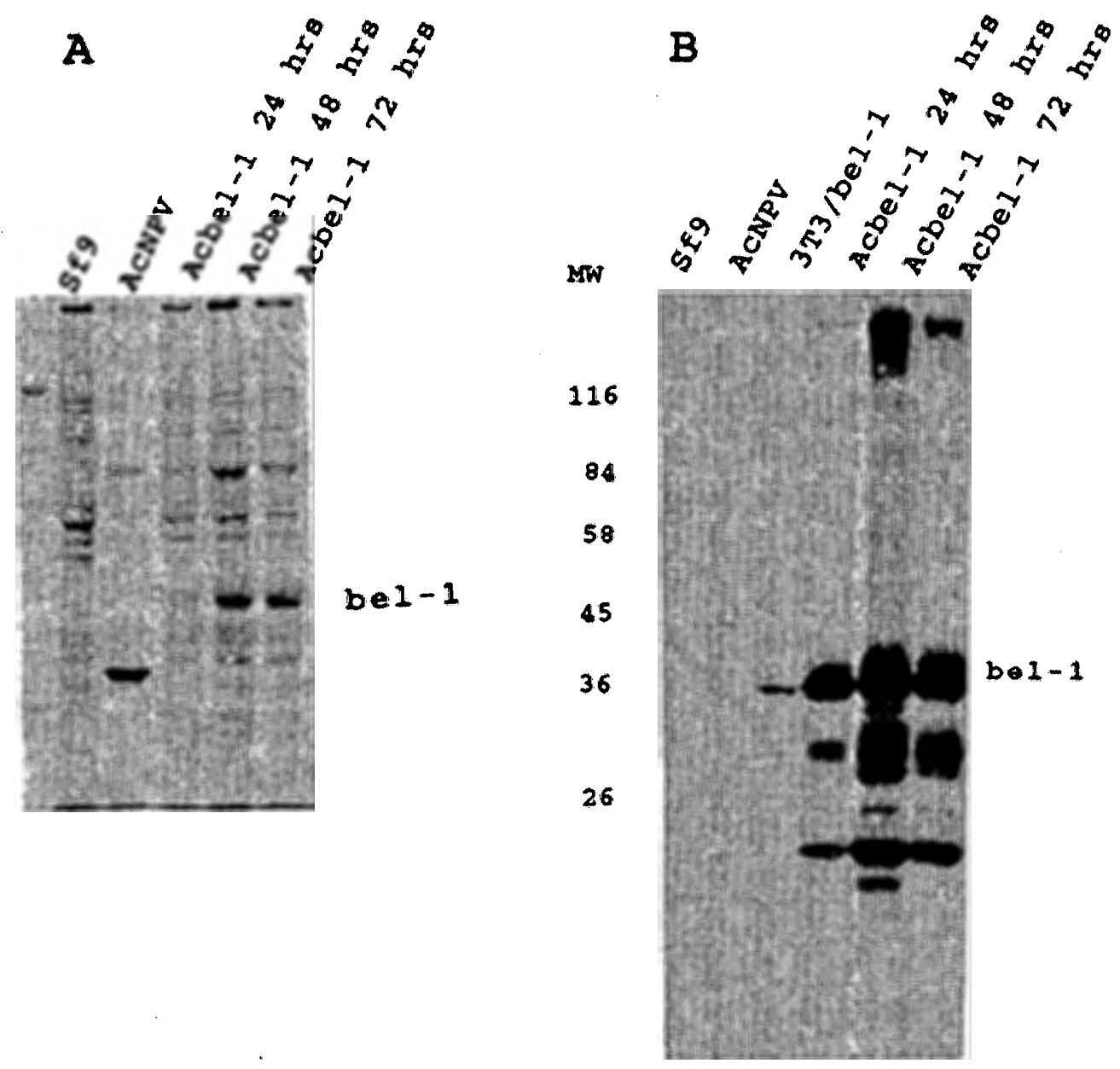

Fig. 2. (A) Coomassie blue stained SDS-10\% PAGE of lysates from uninfected, AcNPV infected and Sf9 cells which were infected with Acbel-1 for 24,48 , and $72 \mathrm{~h}$, respectively. In the lane with lysate from AcNPV infected cells the approximately $29 \mathrm{kD}$ polyhedrin protein is detected as a prominent band, while in Acbel-1 infected cell lysates a novel protein with an approximate molecular weight of $36 \mathrm{kD}$ appeared. The production of the recombinant protein was maximal after $48 \mathrm{~h}$ of infection of Sf9 cells with an m.o.i. of 10. The methods of preparation of cell extracts and SDS-PAGE were as described previously (Bräutigam et al., 1993). (B) Immunoblot of Acbel-1 infected Sf9 cells with rabbit anti-bel-1 directed serum. Cellular extracts were prepared from $8 \times 10^{4}$ Sf 9 cells either uninfected, infected with AcNPV, infected with Acbel-1 at an m.o.i of 10 for 24,48 , and $72 \mathrm{~h}$, respectively, and from $1 \times 10^{6} 3 \mathrm{T3}$ cells stably producing bel-1 protein (Rethwilm et al., 1993). Proteins were resolved on SDS-10\% PAGE and semi-dry blotted onto nitrocellulose filter (Schleicher and Schüll). Immune reaction with rabbit serum diluted 1:500 followed by washing, incubation with peroxidase coupled goat anti-rabbit IgG (Dako), and visualization of bands using the ECL chemiluminescence detection system (Amersham) were performed as described (Baunach et al., 1993). The $36 \mathrm{kD}$ bel-1 protein was detected in lysates from $3 \mathrm{~T} 3 /$ bel-1 cells and from Sf9 cells infected with Acbel-1. Due to the intensifying capacity of the ECL detection system used, other bel-1 antibody reactive proteins smaller than $36 \mathrm{kD}$ were also detected in lysates from Sf9 cells infected with Acbel-1. These proteins may represent degradation products of bel-1.

protein was of the same electrophoretic mobility in SDS-PAGE as a bel-1 antiserum reactive protein in extracts from NIH 3T3 cells which were stably transfected with a bel-1 expressing retroviral vector (Rethwilm et al., 1993), indicating that the novel protein is indeed bel-1. The time course of bel-1 expression in Sf9 
cells revealed that bel-1 was readily detectable in cells infected for $24 \mathrm{~h}$. The production of recombinant protein was maximal after $48 \mathrm{~h}$. Other bel-1 reactive proteins smaller than $36 \mathrm{kD}$ were also detected which might represent degradation products of bel-1.

Bel-1 is a nuclear protein when expressed in mammalian cells (Keller et al., 1991). The nuclear localization signal has been mapped to a basic stretch of amino acids between positions 211 and 225 (Venkatesh et al., 1993; He et al., 1993). To determine whether the expressed bel-1 was transported to the nucleus, Acbel-1 infected Sf 9 cells were analyzed by indirect immunofluorescence (IFA). A nuclear fluorescence was readily observed in recombinant infected cells (Fig. 3A) indicating that the nuclear localization signal was also active in insect cells. No immunofluorescence was seen in cells infected with AcNPV (Fig. 3B) or in unin-
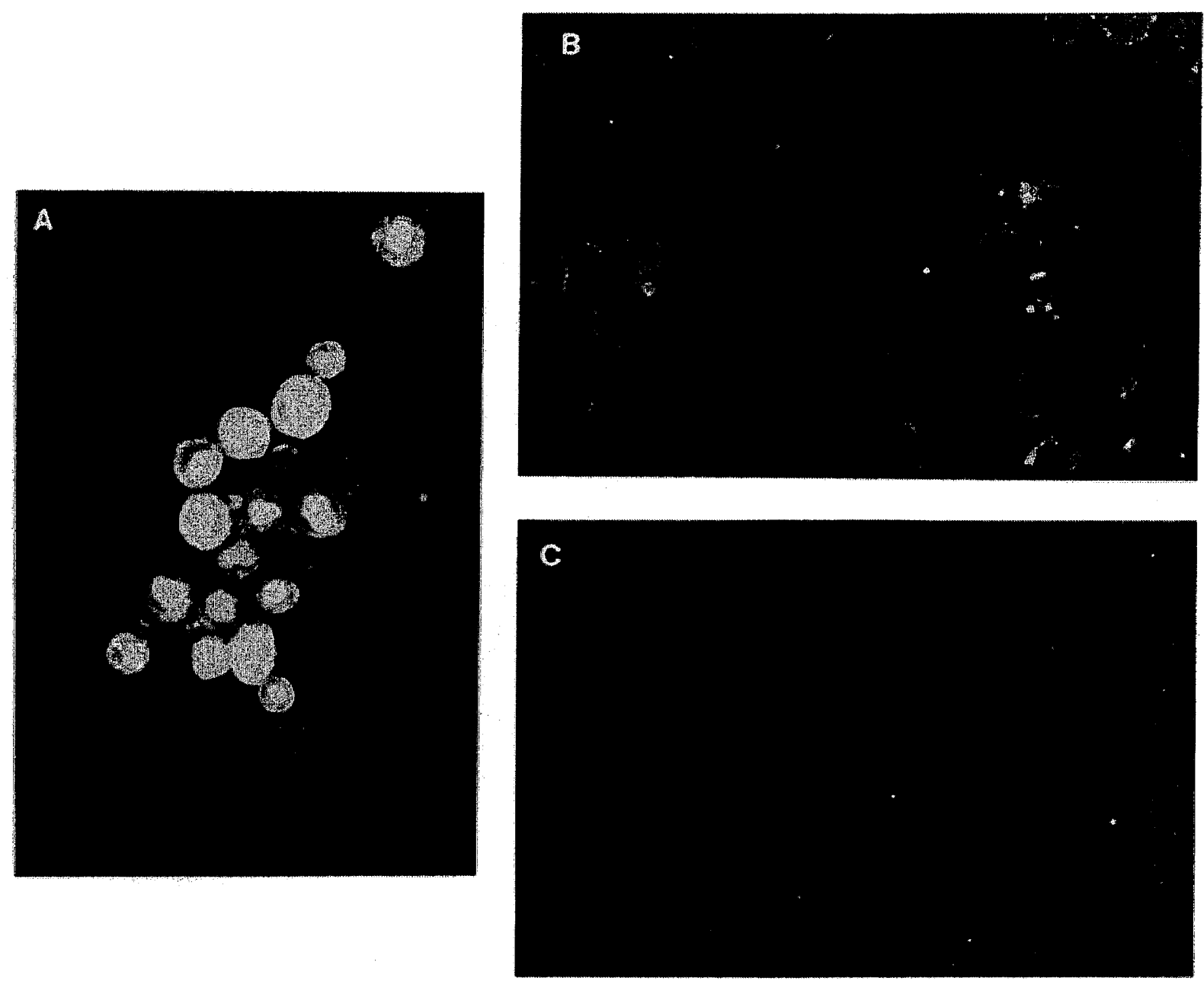

Fig. 3. Immunofluorescence of recombinant baculovirus infected cells. Infected Sf 9 cells were incubated with polyclonal rabbit serum directed against bel-1 followed by fluorescein-conjugated second antibody from goat. IFA was performed as described (Prehaud et al., 1989) with 1:500 diluted first and 1:1000 diluted second antibody. Total immunofluorescence was done using acetone fixed, permeabilized cells (A, B). Surface immunofluorescence was examined by using non-fixed cells (C). (A) Recombinant Acbel-1 infected cells, total immunofluorescence; (B) AcNPV wild type baculovirus infected cells, total immunofluorescence; (C) Acbel-1 infected cells, surface immunofluorescence. 
fected Sf9 cells (not shown). To support specifically intracellular localization of bel-1 indirect immunofluorescence antibody staining was done on cells without fixation and permeabilization (Fig. 3C). No surface or background fluorescence on Acbel-1 infected cells was observed.

The baculovirus expression system has been used extensively for the expression of proteins regulating the expression of viral and non-viral genes (for review see Luckow and Summers, 1988; Bishop, 1992). The recombinant bel-1 protein described in this study may be of use in determining the, as yet, unclear mechanism of action of this novel viral transactivator protein in a more precise manner than with the prokaryotically expressed bel-1 that has been used in previous studies (Venkatesh et al., 1993; Erlwein and Rethwilm, 1993).

\section{Acknowledgements}

We thank Lee Dunster for critically reading the manuscript and Sibylle Retzbach for expert technical assistance. The AcRP23-lacZ baculovirus was kindly provided by R.D. Possee, Institute of Virology, Oxford, UK. This work was supported by the Deutsche Forschungsgemeinschaft (SFB 165). L.H. was supported by a Fellowship from the People's Republic of China.

\section{References}

Aguzzi, A., Wagner, E.F., Netzer, K.-O., Bothe, K., Anhauser, I. and Rethwilm, A. (1993) Am. J. Pathol. 142, 1061-1072.

Baunach, G., Maurer, B., Hahn, H., Kranz, M. and Rethwilm, A. (1993) J. Virol. in press.

Bishop, D.H.L. (1992) Semin. Virol. 3, 253-264.

Bothe, K., Aguzzi, A., Lassmann, H., Rethwilm, A. and Horak, I. (1991) Science 253, 555-557.

Bräutigam, S., Snezhkov, E. and Bishop, D.H.L. (1993) Virology 192, 512-524.

Erlwein, O. and Rethwilm, A. (1993) Virology in press.

Flügel, R.M. (1991) J. AIDS 4, 739-750.

Flügel, R.M., Rethwilm, A., Maurer, B. and Darai, G. (1987) EMBO J. 6, 2077-2084.

He, F., Sun, J.D., Garrett, E.D. and Cullen, B.R. (1993) J. Virol. 67, 1896-1904.

Hooks, J.J. and Detrick-Hooks, B. (1981) In: E. Kurstak and C. Kurstak (Eds.), Comparative Diagnosis of Viral Diseases, Vol. 4, pp. 599-618. Academic Press, New York.

Keller, A., Partin, K.M., Löchelt, M., Bannert, H., Flügel, R.M. and Cullen, B.R. (1991) J. Virol. 65, 2589-2594.

Kupiec, J.-J., Kay, A., Hayat, M., Ravier, R., Peries, J. and Galibert, F. (1991) Gene 101, 185-194.

Lee, K.J., Lee, H. and Sung, Y.C. (1993) J. Virol. 67, 2317-2326.

Löchelt, M., Zentgraf, H. and Flügel, R.M. (1991) Virology 184, 43-54.

Luckow, V.A. and Summers, M.D. (1988) Bio/Technology 6, 47-55.

Matsuura, Y., Possee, R.D., Overton, H.A. and Bishop D.H.L. (1987) J. Gen. Virol. 68, 1233-1250.

Maurer, B., Bannert, H., Darai, G. and Flügel, R.M. (1988) J. Virol. 62, 1590-1597.

Mergia, A., Shaw, K.E.S., Pratt-Lowe, E., Barry, P.A. and Luciw, P.A. (1991) J. Virol. 65, 2903-2909.

Possee, R.D. and Howard, S.C. (1987) Nucleic Acids Res. 15, 10233-10248.

Prehaud, C., Takehara, K., Flamand, A. and Bishop, D.H.L. (1989) Virology 173, 390-399.

Renne, R., Friedl, E., Schweizer, M., Fleps, U., Turek, R. and Neumann-Haefelin, D. (1992) Virology 186, 597-608. 
Rethwilm, A., Darai, G., Rösen, A., Maurer, B. and Flügel, R.M. (1987) Gene 59, 19-28.

Rethwilm, A., Baunach, G., Netzer, K.-O., Borisch, B. and ter Meulen, V. (1990) Nucleic Acids Res. 18, 733-738.

Rethwilm, A., Erlwein, O., Baunach, G., Maurer, B. and ter Meulen, V. (1991) Proc. Natl. Acad. Sci. USA 88, 941-945.

Rethwilm, A., Baunach, G., Jordan, I., Kranz, M. and Aguzzi, A. (1993) (submitted).

Teich, N. (1982) In: R. Weiss, N. Teich, H. Varmus and J. Coffin (Eds.), RNA Tumor Viruses, pp. 25-207. Cold Spring Harbor Laboratory, Cold Spring Harbor, NY.

Venkatesh, L.K., Theodorakis, P.A. and Chinnadurai, G. (1991) Nucleic Acids Res. 19, 3661-3666.

Venkatesh, L.K., Yang, C., Theodorakis, P.A. and Chinnadurai, G. (1993) J. Virol. 67, 161-169.

Weiss, R.A. (1988) Nature 333, 497-498. 